\title{
TEMPLE AND HOLINESS IN 1 CORINTHIANS $\mathbf{5}^{1}$
}

\author{
Brian S. Rosner
}

Why must the incestuous man be expelled from the Corinthian É $\kappa \kappa \lambda \eta \sigma(\alpha$ in 1 Corinthians 5? Paul Minear concedes concerning this passage that it may be easy to grasp the commands Paul gave, but it is far from easy to grasp the reasoning that lay behind these commands' ${ }^{2}$ An important motif of exclusion from the community in the OT and early Judaism is temple and holiness; sinners were excluded to maintain the sanctity of God's temple. ${ }^{3}$ Following a survey of the OT/Jewish evidence for this motif, ${ }^{4}$ this short study considers whether one of the reasons Paul insists on the expulsion of the sinner in 1 Corinthians 5 is in order to restore the holiness of God's temple, the church.

${ }^{1}$ I would like to acknowledge the helpful advice and insight of Dr. William Horbury and Mr. John Knight in the writing of this paper.

2Paul S. Minear, 'Christ and the Congregation: 1 Corinthians 5-6', Review and Expositor LXXX/3 (1983) 341.

${ }^{3}$ Two other reasons for exclusion taught in Scripture include a covenant and a corporate responsibility motif; sinners are expelled because of breach of covenant and because of guilt by association. On the covenant and holiness motifs see Göran Forkman, The Limits of the Religious Community (Lund, CWK Gleerup 1972) 70-8. The presence of the three motifs in 1 Cor. 5 will be explored fully in the author's forthcoming Cambridge University PhD Thesis, 'Paul's Use of Scripture for Ethics in 1 Corinthians 5-7'. See also the author's

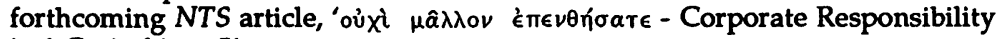
in 1 Corinthians $5^{\prime}$.

${ }^{4}$ For examples of community exclusion outside Biblical influence see Gerald J. Blidstein, 'Atimia: A Greek Parallel to Ezra X.8 and to Post-Biblical Exclusion from the Community', VT 24 (1985) 357-60; and S.C. Barton and G.H.R. Horsley, 'A Hellenistic Cult Group and the New Testament Churches', Jahrbuch für Antike und Christentum 24 (1981) 7-41. Cf. C.K. Barrett, A Commentary on the First Epistle to the Corinthians (London, A. \& C. Black 1968) 123: 'Any community inculcating moral standards ... is bound to recognize a degree beyond which transgression of its code becomes intolerable'. 
Holiness is associated with community exclusion in the Pentateuch through two terms, $ם 7 \pi^{5}$ and $17{ }^{6}, 6$ which arguably have links with 1 Corinthians 5:5. In the Scriptures חר is associated with holy war and is a curse directed against people and objects which must be excluded because of contact with foreign gods. In Deuteronomy 7:26 and 13:14-18 the 'ban' is imposed because of the illicit spoils of war and outright idolatry respectively (cf. בדל in Deut. 29:20). Along with the common כרו formulae of the first four books of the Pentateuch, ${ }^{7}$ this material emphasises the holiness of Yahweh and the need for Israel to be holy. Contamination is also a common theme; whoever takes possession of a devoted thing must himself be devoted, along with his house and even town. Thus in the holiness motif, a person or thing must be removed because of the holiness of God who has sanctified the community.

Related to this holiness motivation for exclusion from the community is OT teaching on exclusion from the temple. William Horbury's study of the practice of excommunication in pre-rabbinic Judaism ${ }^{8}$ argues that throughout the post-exilic period the laws of temple admission legislated in Deuteronomy 23:2-9(1-8) carried the implication of community exclusion. ${ }^{9}$

\footnotetext{
${ }^{5}$ The injunction 'you are to deliver this man to Satan for the destruction of the flesh' in 1 Cor. 5:5 has been compared by Adolf Deissman, Light from the Ancient East (London 1927) 303, Hans Conzelmann, 1 Corinthians (Philadelphia, Fortress 1975) and others to pagan curse formulae. Göran Forkman, The Limits of the Religious Community, 143, however, has suggested an alternative background for this verse. He describes it as 'a solemn dynamic surrender to the power of evil', a 'devotion', comparable to various OT curses including the חר of Deut. 7:26 and 13:14-18 (and Deut. 27 and 28).

${ }^{6}$ The verbal form of ${ }^{\lambda} \lambda \in$ pos (destruction) in 1 Cor 5:5 is used four times in the LXX to translate כרת (Num. 4:18; Jdg. 6:25,28,30), a prominent term in the teaching of scripture on community exclusion. Although these four texts do not address community exclusion, the related compound, $\dot{\xi} \xi \circ \lambda \in \theta \rho \circ$ (destroy completely), does translate the majority of occurrences of כרת in the Pentateuchal community exclusion formulae (cf. Gn. 17:4; Ex. 12:15,19; 30:33; 31:14; Lev. 17:4,9,14; 18:29; 19:8; 20:17,18; 22:3; 23:29; Num. 4:18; 9:13; 15:30; 19:20) and the verb $\dot{\xi} \xi \circ \lambda \in \theta \rho \in v^{\prime} \omega$ also appears in Jos. 7:25 in the story of Achan's expulsion from the community.

כרת formulae are distinguished by ritual offences (Gn. 17:14; Ex. 12:15,19; 30:33,38; 31:4; Lv. 7:20,25,27; 17:4,9,14; 19:8; 22:3; 23:29; Num. 4:18; 9:13; 19:13,20; $1 \mathrm{Sa}$. 2:33) which have points of contact with the cult and holiness.

${ }^{8} W$. Horbury, 'Extirpation and Excommunication', VT, XXXVI/1 (1985) 13-38.

${ }^{9}$ Horbury, ibid., 25.
} 
Horbury demonstrates that during the Second Temple period the scope of the laws of admission to the assembly found in Deuteronomy 23:2-9(1-8) were expanded beyond stipulations of physique and descent to include moral requirements. ${ }^{10}$ Biblical evidence for this evolution includes the 'entrance-torot' (Ps. 15;24:3-5; Is. 23:14-1711), the exclusion of 'rebels' (הפוטעים) in Ezekiel 20:38-40 from the future congregation, and the indictment of Israel for admitting into the sanctuary aliens who are 'uncircumcised in heart' in Ezekiel 44:6-9. Josephus and Philo build upon this biblical background and 'take Deuteronomy 23 to exclude not only aliens and defective Jews, but also gravely-offending Jewish sinners'. ${ }^{12}$ A holiness motif is most clearly perceived in 1 Corinthians 5 in light of this development in the use of Deuteronomy 23:2-9(1-8).

The likelihood that Deuteronomy 23:2-9(1-8) played a role in the formation of Paul's thinking in 1 Corinthians 5 is increased by the fact that the previous verse in Deuteronomy addresses the very question with which Paul is engaged: 'A man is not to marry his father's wife; he must not dishonour his father's bed'. That Paul linked the two passages has every possibility since, as Horbury observes: 'The admissionregulations of Deuteronomy 23:2-9(1-8) were linked in rabbinic exegesis with 23:1(22:30), and correspondingly understood, as by Targum Pseudo-Jonathan, as marriage laws'. ${ }^{13}$

It would hardly be surprising, therefore, to find in 1 Corinthians 5 the expulsion of the sinner connected with the theme of temple and holiness. ${ }^{14}$ Why must the offender be delivered to Satan for 'destruction' (5:5)? Surely the best explanation is given only 27 verses before chapter 5 in the solemn affirmation: 'Do you not know that you are God's temple

\footnotetext{
${ }^{10}$ Ibid., 26,27 .

${ }^{11}$ Though applied in the LXX to the qualifications of a prophet, Targum Isaiah 33:14-17 maintains the original context of admission.

${ }^{12}$ Horbury, op. cit., 26. For example, both apply $23: 2(1)$ to the voluntary effeminate (not just to the born eunuch). See Philo, The Special Laws 1:324-45; Josephus, Ant. 4:290f.

${ }_{13}^{13}$ Horbury, op. cit., 25.

${ }^{14}$ Temple imagery is prevalent in both Corinthian epistles. The church is identified as the vaòs $\theta \in 0$ in in 2 Cor. 6:16. In 1 Cor. 6:19 (significantly for 1 Cor. 5) the need for sexual purity is linked to individual Christians being the temple of the Holy Spirit.
} 
... If anyone destroys God's temple, God will destroy him. For God's temple is holy, and that is what you are' (3:16-17).

There are good reasons for thinking that Paul's comments in 1 Corinthians 3:16-17 find their roots in the OT and are part of the same temple/holiness tradition mentioned above (which largely grew out of Deut. 23:2-9). ${ }^{15}$ The very conception of the community as a temple is a scriptural theme, where the divine indwelling is not just of a sanctuary but of a people. ${ }^{16}$ The Peshitta of Jeremiah 7:4 states the thought explicitly: 'the temple of the Lord, the temple of the Lord, you (plural) are the temple of the Lord. ${ }^{\prime 17}$ That this seed thought of the community as a building or temple was nourished in early Jewish teaching is clear from 1 QS $8: 4-7^{18}$ and Philo's $O n$ Sobriety 66 and On Abraham 56. ${ }^{19}$

Even some of the details of 1 Corinthians 3:16-17 have Biblical/Jewish precedents. Paul's notion of 'the Spirit of God' rather than simply 'God' dwelling in the Temple is found in Josephus' account of Solomon's temple (Ant. 8:114). The connection of temple with judgement in 1 Corinthians 3:16-17 is reminiscent of Numbers $1: 51 ; 3: 10,38 ; 4: 20 ; 19: 20$. Paul's concern for a purified temple also brings to mind Israel's sin offering, which was designed to cleanse the tabernacle from defilement. $^{20}$ The warning in 1 Corinthians 3:17, as stated in

${ }^{15}$ Contra $\mathrm{H}$. Wenschkewitz, 'Die Spiritualisierung der Kultusbegriffe Tempel, Priester und Opfer im Neuen Testament', Angelos IV (1932) 70-230, who stresses the formative role of Hellenistic thought about the individual as divinely indwelt as the major background for Paul's use of temple imagery.

${ }^{16}$ Ex. 25:8; 29:45; Lv. 26:11f; Ezk. 11:16; 37:26-28; Ps. 114:2; cf. W. Horbury, 'New Wine in Old Wine Skins: IX. The Temple', ET 86 (1974-75) 36-42.

${ }^{17}$ Cf. F.C. Burkitt, Early Christianity Outside the Roman Empire (Cambridge,1899) 32; William L. Holladay, Jeremiah 1: A Commentary on the Book of the Prophet Jeremiah Chapters 1-25 (Philadelphia, Fortress Press 1986) 242.

${ }^{18}$ Cf. 5:4-7; 8:8-10; 9:3-6. See G. Klinzing, Die Umdeutung des Kultus in der Qumrangemeinde und im Neuen Testament (Göttingen 1971) 70.

${ }^{19} \mathrm{Cf}$. V. Nikiprowetzky, 'Temple et Communauté', REJ 126 (1967) 7-25 and 'Le Nouveau Temple', REJ 130 (1971) 5-30. On the idea of a temple-like community in the pesher on 2 Sam. 7:10-14 in 4Q174 see Devorah Dimant, '4QFlorilegium and the idea of the Community as Temple', in Hellenica et Judaica: Hommage d Valentin Nikiprowetzky, A. Caquot, M. Hadas-Lebel and J. Riaud (edd.) (Leuven-Paris, Editions Peeters 1986) 165-89.

${ }^{20}$ See Lv. 4:1-5:15; 15:31; 16:19; Cf. J. Milgrom, 'Two Kinds of Hatta't Sacrifice', VT 26 (1976) 333-7, and Gordon J. Wenham, The Book of Leviticus, NICOT 
terms of talionic justice ( $\phi \theta \in\{\rho \in \mathrm{l} \ldots \phi \theta \in\{\rho \in \mathrm{l}$ ), is reminiscent (an allusion?) of the LXX of Joshua 7:25 (a key excommunication text in the LXX): 'And Joshua said to Achan, why have you destroyed us? The Lord will destroy you as at this day. ${ }^{21}$ Indeed, appropriate judgement is a feature of other OT discipline texts (eg. Lev. 26:23-5; cf. 26:27-28,40-1). In context, 1 Corinthians $3: 16-17$ is introduced by $3: 9-15$, the building imagery of which also fits an OT sanctuary background. ${ }^{22}$ Paul makes the connection of his temple metaphor with the OT explicit in 2 Corinthians 6:16ff where Leviticus 26:12 and Ezekiel 37:27 are quoted.

Two groups of observations support the case for reading 1 Corinthians 5 (especially 5:5) with 3:16-17 and an OT temple/holiness motif in mind. ${ }^{23}$ First, certain features of 3:1617 suggest its affinity with chapter 5 . 1 Corinthians 3:16-17, in contrast to $6: 19$, describes the body corporate as God's temple (you [plural] are God's temple [singular]; cf. 3:9b: 'you [plural] are God's building'), which we are claiming is Paul's presupposition in 1 Corinthians 5 . The characteristic of the temple to which Paul draws attention in 3:16-17 is its $\dot{\alpha} \gamma 2 \alpha \sigma \mu o ́ s$ (holiness), which carries a demand for the maintenance of purity (which is developed in 1 Cor. 5:6-8). The punishment in

(Grand Rapids, Eerdmans 1979) 84-103, who translate חשאת as 'purification offering'.

${ }^{21}$ It is worth noting that a prominent word for 'the apostates' in the twelfth benediction of the Tefillah (see Emil Schürer, The History of the Jewish People in the Age of Jesus Christ, (Edinburgh, T \& T Clark 1979) revised by Geza Vermes, Fergus Millar, and Matthew Black, 455-63), the Benediction of the Minim, is and the destroyed ones'. On the Biblical roots of this benediction see W. Horbury, 'The Benediction of the Minim and Early Jewish-Christian Controversy', JTS XXXIII/1 (1982) 19-61.

${ }^{22}$ Cf. Archibald Robertson and Alfred Plummer, A Critical and Exegetical Commentary on the First Epistle of St Paul to the Corinthians, ICC (Edinburgh,

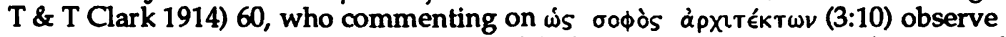
that: "The same expression is found in LXX of Isa. iii. 3, and бoфòs is frequent of the skilled workmen who erected and adorned the tabernacle (Exod. xxxv. 10,25, xxxvi. 1,4,8)'.

${ }^{23}$ In their studies of the temple motif in Paul's thought, Raymond Corriveau, The Liturgy of Life, (Paris, Brouwer 1970) esp. 48-68,187-92; Ronald Y.K. Fung 'Some Pauline Pictures of the Church', EQ 53 (1981) 89-107; and I.H. Marshall 'Church and Temple in the New Testament', TynB 40.2 (1989) 203-22 make no mention of 1 Cor. 5 . The only author to my knowledge who connects 1 Cor. 5 with 3:16-17, Micheal Newton, The Concept of purity at Qumran and in the letters of Paul (Cambridge 1985) 89, does so in passing. 
1 Corinthians 3:15 ('if any man's work is burned up, he will suffer loss, though he himself will be saved, but only as through fire') has been plausibly compared by C.K. Barrett to the 'destruction' of 5:5: 'the man's essential self will be saved with the loss not only of his work but of his flesh'.24 1 Corinthians $3: 17$ and 5:5 are also linked in terms of genre/function: both texts are, as Robert M. Grant explains, holy law. ${ }^{25}$

Secondly, 1 Corinthians 3:16-17 may well anticipate 5:1-13 since it is not uncommon for Paul in this epistle and elsewhere to set up a later discussion in such a manner. That Paul is capable of pre-empting later material in his epistles by way of terse, proleptic, summary remarks is clear from the intricately structured epistle to the Romans. ${ }^{26}$ In spite of the conspicuously occasional nature of 1 Corinthians (Paul responds to verbal then written reports), the epistle evidences a greater degree of compositional coherence than is commonly recognized. Whereas most commentators admit development of thought within sections of 1 Corinthians, ${ }^{27}$ links between sections may also be observed. The introductory thanksgiving (1:4-9), as is customary in Paul's letters, presents the main themes of the entire epistle. ${ }^{28}$ The theme of spiritual gifts (addressed in chs. $12-14$ ) is introduced in 1:4 ( $\chi \alpha \alpha^{\prime} p l \tau \imath$ refers here specifically to

\footnotetext{
${ }^{24}$ Barrett, op. cit., 127. Cf. The 'destruction' in Jos. 7:12,15 which is also 'by fire'. See also testing by fire in Pro.17:3; Wisd. 3:6.

${ }^{25}$ 'Holy Law in Paul and Ignatius', in The Living Text: Essays in Honor of Ermest W. Saunders, Dennis E. Groh and Robert Jewett (edd.) (London, University Press of America 1985) 65-71.

${ }^{26}$ Klyne Snodgrass, 'Spheres of Influence: A Possible Solution to the Problem of Paul and the Law', JSNT 32 (1988) 104, comments: 'Frequently he (i.e. Paul) introduces a point briefly only to return to it later for detailed treatment. In 3.1-4 he raises issues that are not dealt with in detail until chs. 9-11. In 3.8 he asks a question that is dealt with in $6.1 \mathrm{f}$. In 3.31 he makes a statement that is explained in chs. 7-8. . . in 5.20 Paul brings law into connection with sin, but what he means by that statement is not clear until 7.7-13'.

${ }^{27}$ On the 'A-B-A' form of argumentation in chs 1-3, 7:25-40, 8-10, and 12-14, see J. Collins, 'Chiasmus, the 'ABA' Pattern and the Text of Paul', in Studia Paulinorum Congressus Internationalis Catholicus (Rome 1963) 2:575-84. Cf. also Gordon D. Fee, The First Epistle to the Corinthians, NICNT (Grand Rapids, Eerdmans 1987) 15,16.

${ }^{28}$ Peter O'Brien, Introductory Thanksgiving in the Letters of Paul, Supp to NT 49 (Leiden, Brill 1977) 261-3, has observed four functions of such sections in Paul's letters: they serve a pastoral (revealing concern), didactic, paraenetic, and epistolary function. Our concern here is only with the last purpose.
} 


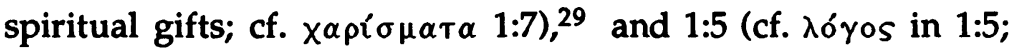
$12: 8 ; 14: 9,19,36$; and $\gamma \nu \omega \hat{\omega}$ เ $s$ in $1: 5 ; 8: 1,7,10,11 ; 12: 8 ; 13: 2,8$; $14: 6),{ }^{30}$ Paul's proclamation to the Corinthians in 1:6 (cf.

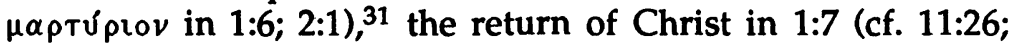

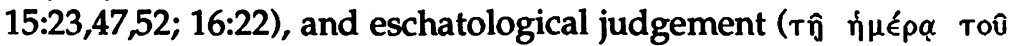
kupiou) in $1: 8$ (cf. $3: 13 ; 4: 3 ; 5: 5)$. The issue of unity (1:10-4:21; especially $1: 10-17)$ is anticipated in the address in 1:2: av่ $1 \hat{\omega} v$

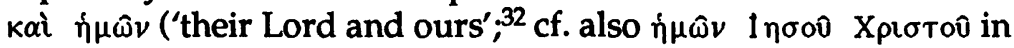
$1: 10) .{ }^{33}$

As Paul dictated the rest of the epistle, without detracting from the subject at hand, he occasionally made a point which would have secondary application to a subject to be dealt with later. In 2:7-8 the connection of believers' ultimate glorification to their union with Christ (note repetition of $\delta \delta \xi \alpha)$ is a precursor of 1 Corinthians 15 where Paul's chief point is that Christ's resurrection guarantees the resurrection of believers. ${ }^{34}$ The believer's possession of the Spirit, foundational to $3: 16 ; 6: 19 ; 12: 13$, is introduced emphatically in 2:12.35 In 6:12-14 Paul makes several pregnant statements that are expounded later in the letter. ${ }^{36}$ The question of unity

${ }^{29}$ See Gordon Fee, op. cit., 37, for validation of this point.

${ }^{30}$ Michael Goulder in a forthcoming NTS article in 1 Cor. observes that the

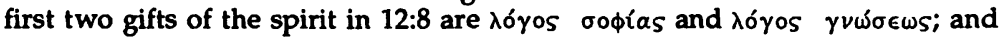
these correspond with 1:5, 'you were enriched in everything, '̇ $\epsilon$ mavì $\lambda o ́ \gamma \omega$

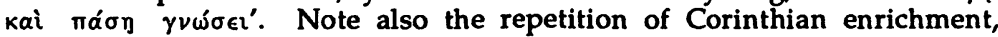
$\pi \lambda$ ou $T \zeta \omega$, in $1: 5$ and 4:8.

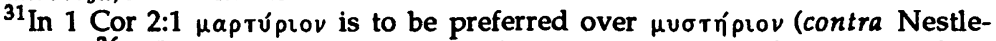
Aland ${ }^{26}$ ). Both external evidence ( $\mu a \rho$ Túpiov has wider geographical distribution, with Alexandrian, Western and Byzantine attestation) and the context (1:17-31 concerns the message about Christ) favour the former reading.

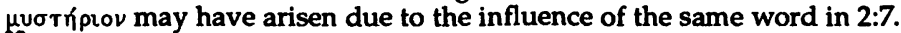

${ }^{32}$ The phrase is better taken as a possessive genitive with kupiou (most

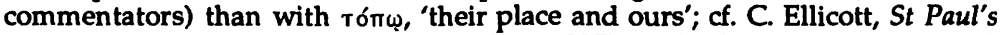
First Epistle to the Corinthians (London 1887) and Hans Conzelmann, 1 Corinthians, an interpretation correctly labelled by Barrett as 'trite' (op. cit., 34). Ulrich Wickert, 'Einheit und Eintracht der Kirche im Präskript des ersten Korintherbriefes', ZNTW 50 (1959) 73-82, contends that in using this phrase Paul had in mind the exhortation to unity to follow.

${ }^{33}$ Other elements in the opening verses also tune the reader into the question of unity (cf. $\sigma \dot{v} v$ in $1: 2$ and the repetition of $\dot{\eta} \mu \omega \hat{\omega} ; 1: 2,3,7,8,9$ ).

${ }^{34}$ As Barrett, op. cit., 78, explains, $\delta \delta \delta \xi \alpha$ in $2: 7$ is that which 'awaits men in the age to come (e.g. xv. 43)'.

${ }^{3}$ Cf. F.F. Bruce, 1 and 2 Corinthians, NCB (London, Oliphants 1971) 39.

36J.B. Lightfoot, Notes on Epistles of St. Paul (London, Macmillan and Co. 1895)

215: 'It is noticeable that these three verses (12-14) contain the germ of very 
addressed in chapters $1-4$ resurfaces in 11:17-22. ${ }^{37}$ Reading through 1 Corinthians one's mind sometimes harks back instructively to earlier passages. It is this kind of connection we are proposing for 3:16-17 in relation to $5: 1-13.38$ The fact that a letter like 1 Corinthians would have been read through/listened to in its entirety lends further credibility to this proposal of a cumulative reading of 1 Corinthians. 1 Corinthians 3:16-17 would have been ringing in the ears of the letter's recipients when 1 Corinthians 5 was read.

If we are correct in assuming that 1 Corinthians 5 ought to be read with 3:16-17 in mind, then another element in the chapter, in addition to verse 5 , should be mentioned as congruent with a temple theme, namely, verses 7 and 8 . Having cleansed 'the temple' Paul calls upon the congregation to celebrate spiritually the festival of Passover/Unleavened Bread in 1 Corinthians 5:7-8. That this sequence of events sprang to Paul's mind may itself testify to the influence of the OT temple motif since in the OT there is an observable link between cleansing or restoring the temple and celebrating the Passover. Following the 'removal of all defilement from the sanctuary' (2 Chr. 29:5) in order to 're-establish the service of the temple of the LORD' (2 Chr. 29:35), King Hezekiah in 2 Chronicles 30 calls upon the people to celebrate the Passover. Similarly King Josiah after removing the articles of idolatry from the temple and replacing the sacred ark in its rightful place ordered the Israelites to celebrate the Passover and observe the Feast of Unleavened Bread (2 Chr. 35:1-19; $2 \mathrm{Ki}$. 23:1-23). Ezra followed the same pattern; Ezra 6 records first

much which follows in the Epistle: (1) the great principle which is to guide the

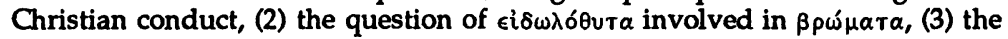
conflict with sensual indulgences, (4) the doctrine of the resurrection of the dead'.

${ }^{37}$ Other less certain connections across the epistle could also be noted such as 3:10-15 in relation to the 'disqualification' in 9:27 and the judgement in 11:29;

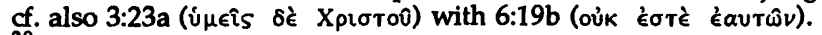

${ }^{38}$ That 1 Cor. 3:16-17 serves more than just the paragraph in which it resides has been suggested, without specific reference to ch. 5 , by Gordon Fee, op. cit., 237: 'the church as God's temple dominates his (Paul's) perspective even when it is not expressed' and by Friedrich Lang, Die Briefe an die Korinther, NTD (Göttingen, Vandenhoeck \& Ruprecht 1986) 69, who notes that 3:16-17 introduces the theme of the holiness of the church which he insists dominates chs. 5 and 6. 
the completion and dedication of the temple (6:13-18), and then a joyous Passover and Feast of Unleavened Bread (6:1922). It is intriguing that even in the Gospels, at the beginning of Jesus' ministry (Jn. 2:12-22) and at its close (Mt. 21:12,13; Mk. 11:15-18; Lk. 19:45-7), as it seems in 1 Corinthians 5, cleansing the temple and celebrating the Passover are connected.

There are good reasons, then, for thinking that 1 Corinthians 3:16-17 provides the theological framework for understanding perhaps the most fundamental reason for the expulsion of the sinner in 5:1-13:39 the sinner must be 'destroyed' because he has defiled the holiness of God's temple, ${ }^{40}$ the church. ${ }^{41}$ A corollary of this holiness motif, contamination, is also present in 1 Corinthians 5 . The sinner must be removed because holiness and unholiness cannot coexist, 'a little leaven leavens the whole lump' $(5: 6){ }^{42}$

\footnotetext{
${ }^{39}$ The fact that ö $\lambda \in \theta \rho \circ$ is used in 5:5 and $\phi \theta \epsilon i \rho \omega$ in 3:17 does not undermine the connection between the two passages. Whereas the former word is better suited to a context of explicit excommunication because of its (previously noted) links with כרו for excommunication; the immediate context of 3:16-17 and its primary application concern the protection of the church from false teachers and division and not excommunication.

${ }^{40}$ It seems that Paul believed along with Deut. 22:21b that nорvєía 'defiles the house' (of one's father).

${ }^{41}$ Adela Y. Collins, 'The Function of Excommunication in Paul', HTR 73 (1980) 263, without drawing attention to temple imagery, comes to a similar conclusion: 'the more or less explicit reason for expelling the incestuous man in 1 Corinthians 5 was to guard the holiness of the community and to avoid offence to the presence of the Holy Spirit'. Hans Conzelmann, op. cit., 96, recognizes the holiness motif in 1 Cor. 5, but, in my view, mistakenly connects it with 6:19 rather than 3:16-17: 'Paul does not explicitly state the ground of his judgement, because the ground is self evident: the community is the temple of God (6:19)'. The findings of this study are in disagreement with Victor C. Pfitzner, Purified Community-Purified Sinner', Australian Biblical Review 30 (1982) 48, who states that (in 1 Cor 5) 'Paul shows, perhaps surprisingly, little or no interest in preserving the holiness of the church on a neo-levitical foundation'.

${ }^{42}$ G.W.H. Lampe, 'Church Discipline and the Interpretation of the Epistles to the Corinthians', Christian History and Interpretation: Studies presented to John Knox, W.R. Farmer, C.F.D. Moule and R.R. Niebuhr (edd.) (Cambridge, CUP 1967), 355, aptly explains the proverb as 'moral contamination of the brotherhood'.
} 